\title{
AnAlisis Getaran PADA GenERATOR MAgnet PERMANEN 1 KW Hasil Rancang Bangun Pusat Penelitian Tenaga Listrik dan MEKATRONIK
}

\author{
Pudji Irasari, Aditya Sukma Nugraha, Muhamad Kasim \\ Puslit Tenaga Listrik dan Mekatronik - LIPI \\ Komplek LIPI, Jl.Cisitu No.21/154D Bandung 40135 \\ Tel: 022-250-3055; Fax: 022-250-4773 \\ pudj002@lipi.go.id; adit003@lipi.go.id; kasime99uh@yahoo.co.id
}

Diterima: 18 Agustus 2010; Direvisi: 23 Agustus 2010; Disetujui: 30 September 2010;

Terbit online: 10 Oktober 2010.

\begin{abstract}
Abstrak
Getaran pada generator merupakan faktor yang penting dalam pembuatan detail desain. Untuk mengetahui perilaku getaran yang terjadi, pengetesan dilakukan dengan vibratiometer. Tujuan penulisan makalah ini adalah untuk memperoleh acuan klasifikasi getaran yang sesuai dengan standar IEC 34-14 dan DIN EN 60034-14. Dalam tulisan ini respon hasil pengujian yaitu kecepatan dan percepatan akan diukur secara analitik sehingga mampu memunculkan nilai yang bisa dipakai untuk membandingkan antara nilai hasil pengujian dengan nilai pada standar IEC 34-14 dan DIN EN 60034-14.
\end{abstract}

Kata kunci : Generator, getaran, kecepatan, percepatan.

\begin{abstract}
Vibration in a generator is an important factor in detail of design. To know the behavior of the vibration, a test is performed using vibratiometer. The aim in writing this paper is to obtain reference classification of vibration that can be viewed on a standard IEC 34-14 and DIN EN 60034-14. In this paper the results of testing, the value of velocity and acceleration, will be measured analytically so as to create value that can be used to compare the value of the test results with the value from 34-14 IEC and DIN EN 60034-14 standards.
\end{abstract}

Keywords: Generator, vibration, kecepatan, percepatan.

\section{Pendahuluan}

Suatu benda yang diam apabila dibebani oleh suatu gaya akan menimbulkan gerakan sekitar titik setimbang. Getaran akibat beban dinamis yang diterima oleh mesin apabila dilakukan dengan rutin dan dengan periode yang lama akan menimbulkan getaran siklis yang dapat menyebabkan kelelahan pada material [1]. Getaran dalam gerakan melingkar yang terjadi pada mesin putar memang tidak bisa dihindari, tetapi dengan pengujian besar getaran yang terjadi, akan dapat diketahui getaran tersebut menyebabkan kerusakan atau tidak.

\section{A. Latar Belakang Masalah}

Penyebab umum getaran pada mesin putar adalah pembebanan dinamis dan kelonggaran. Pembebanan dinamis terjadi apabila mesin putar dipakai dalam waktu yang relatif lama. Hal ini akan mempengaruhi struktur komponen yang lain misalnya, fondasi mesin, karena tata letak geometris dari fondasi akan ikut menentukan besaran getaran yang akan diterima oleh mesin tersebut. Disamping itu apabila dilakukan pembebanan yang rutin maka bentuk serta ikatan fondasi dengan tanah akan menentukan besar getaran yang akan diterima oleh mesin [1].

Tingkat toleransi kelonggaran pada mesin juga memegang peranan yang penting dalam desain suatu alat. Menurut studi yang dilakukan, bahwa cacat dan kelonggaran bantalan merupakan penyebab tersering kerusakan pada motor induksi [2]. Disamping itu kelonggaran bantalan juga dapat disebabkan oleh kelelahan siklis dari komponen tersebut, yaitu kelelahan material akibat tegangan geser yang bekerja secara siklis [3]. Selain kesalahan mekanis pada generator terdapat beberapa kasus yang bisa menyebabkan gerakan putar pada generator menjadi tidak seimbang dan kacau. Penyebabnya antara lain adalah tingginya arus yang mengalir maupun gangguan elektrik lainnya, yang bisa menyebabkan kekacauan pada sistem. Apabila kesalahan ini dibiarkan dalam jangka waktu yang lama, akan menyebabkan hilang daya, bergesernya orbit putar sehingga menyebabkan putaran mesin lebih berat [4]. Secara awam getaran bisa dilihat dan dirasakan, akan tetapi 
untuk mendeteksi besaran getaran yang terjadi, diperlukan analisis numerik dari beberapa parameter yang diambil.

\section{B. Latar Belakang IPTEK}

Hasil pada pengujian akan dibandingkan dengan standar yang ada yaitu pada standar IEC 34-14 dan DIN EN 60034-14. Standar ini dipakai karena merupakan acuan internasional batas nilai getaran pada mesin putar elektrik. Pada standar IEC 34-14 dijelaskan tentang besaran nilai getaran yang diijinkan untuk pengujian mesin tanpa suspensi, pegas maupun tanpa landasan yang bersifat elastis [5]. Pada standar ini maksimum ketinggian poros mesin putar yang akan diukur adalah $630 \mathrm{~mm}$, sedangkan pada generator adalah $151 \mathrm{~mm}$, sehingga generator yang diuji termasuk dalam kriteria Tabel 1 dibawah ini. Pada IEC 34-14 ada tiga level pengujian, yaitu: Normal $(\mathrm{N})$ untuk mesin putar secara umum, Reduced (R) untuk mesin putar yang perlu ketelitian seperti mesin bor maupun mesin milling dan yang terakhir Special (S) untuk mesin putar yang memerlukan ketelitian yang tinggi, misalnya mesin gerinda dan mesin balance. Dalam hal ini generator yang diuji masuk ke dalam level normal [4].

Tabel 1.

Maksimum kecepatan getaran yang diijinkan berdasar standar IEC 34-14.

\begin{tabular}{|c|c|c|c|c|c|}
\hline \multirow{3}{*}{ Grade } & \multirow{2}{*}{$\begin{array}{c}\text { Rated Speed } \\
(\mathrm{rpm})\end{array}$} & \multicolumn{4}{|c|}{$\begin{array}{c}\text { Maximum r.m.s Values of Vibration Velocity }(\mathrm{mm} / \mathrm{s}) \\
\text { Machine Measure in }\end{array}$} \\
\cline { 3 - 6 } & & $56 \leq \mathrm{H}<132$ & $132 \leq \mathrm{H}<225$ & $225 \leq \mathrm{H}<400$ & $400 \leq \mathrm{H}<630$ \\
\hline \multirow{2}{*}{$\mathrm{N}$} & $600 \leq \mathrm{n} \leq 1800$ & 1.8 & 1.8 & 2.8 & 2.8 \\
& $1800<\mathrm{n} \leq 3600$ & 1.8 & 2.8 & 4.5 & 4.5 \\
\hline \multirow{2}{*}{$\mathrm{R}$} & $600 \leq \mathrm{n} \leq 1800$ & 0.71 & 1.12 & 1.8 & - \\
& $1800<\mathrm{n} \leq 3600$ & 1.12 & 1.8 & 2.8 & - \\
\hline \multirow{2}{*}{$\mathrm{S}$} & $600 \leq \mathrm{n} \leq 1800$ & 0.48 & 0.71 & 1.12 & - \\
& $1800<\mathrm{n} \leq 3600$ & 0.71 & 1.12 & 1.8 & \\
\hline
\end{tabular}

Disamping Tabel IEC 34-14 diatas, tulisan ini juga membandingkan antara hasil percobaan pengambilan data getaran generator dengan standar DIN EN 60034-14, seperti yang terlihat pada Tabel 2 dibawah ini. Pada standar ini pembacaannya mirip dengan standar IEC 34-14, hanya untuk spesifikasi frekuensi getaran antara $10-1000 \mathrm{~Hz}[6]$.

Tabel 2.

Batas maksimum kecepatan getaran yang diijinkan berdasar standar DIN EN 60034-14.

\begin{tabular}{|c|c|c|c|c|}
\hline \multirow{2}{*}{ Grade } & \multirow{2}{*}{$\begin{array}{l}\text { Rated } \\
\text { Speed } \\
(\mathrm{rpm})\end{array}$} & \multicolumn{3}{|c|}{$\begin{array}{c}\text { Limits of Vibration Velocity } \\
(\mathrm{mm} / \mathrm{s}) \text { in Frequency Range 10 } \\
\text { up to 1000 Hz sizes }\end{array}$} \\
\cline { 3 - 5 } & & $80-112$ & $132-200$ & $225-400$ \\
\hline $\mathrm{N}$ & $600-3600$ & 1.8 & 2.8 & 3.5 \\
\hline \multirow{2}{*}{$\mathrm{R}$} & $600-1800$ & 0.71 & 1.12 & 1.8 \\
& $1800-3600$ & 1.12 & 1.8 & 2.8 \\
\hline \multirow{2}{*}{$\mathrm{S}$} & $600-1800$ & 0.45 & 0.71 & 1.12 \\
& $1800-3600$ & 0.71 & 1.12 & 1.8 \\
\hline
\end{tabular}

\section{Tujuan Penelitian}

Tujuan dalam penulisan makalah ini adalah untuk memperoleh acuan klasifikasi getaran yang sesuai dengan standar IEC 34-14 yang ada pada Tabel 1 [5] dan DIN EN 60034-14 [6] yang ada pada Tabel 2.

\section{Metodologi PENELitiAn}

\section{A. Objek penelitian}

Generator yang akan diuji adalah generator magnet permanen. Generator ini banyak dipilih oleh pengguna, karena memiliki beberapa kelebihan, antara lain adalah biaya produksinya murah, magnet dapat dibuat sesuai dengan cetakan yang dinginkan, memiliki sifat magnet yang seragam, dan kerugian arus edy yang kecil [7]. Secara garis besar, generator memiliki 2 komponen utama, yaitu stator dan rotor. Stator yang dibuat terdiri dari beberapa coil atau kumparan dari kawat tembaga yang dilapisi oleh bahan isolator, sedangkan rotor terdiri dari poros pemutar. Dimensi dan parameter utama yang digunakan pada generator disajikan dalam Tabel 3 di bawah ini.

Tabel 3.

Parameter pada generator.

\begin{tabular}{|l|l|}
\hline \multicolumn{1}{|c|}{ Parameter } & Nilai \\
\hline Tegangan fasa nominal & 169,7 Volt \\
Frekuensi nominal & $50 \mathrm{~Hz}$ \\
Putaran nominal & $333 \mathrm{rpm}$ \\
Jumlah fasa & $3 \mathrm{fasa}$ \\
Kisar lilitan penuh & 1 \\
Kerapatan arus & $5 \mathrm{~A} / \mathrm{mm}^{2}$
\end{tabular}




\begin{tabular}{|l|l|}
\hline \multicolumn{1}{|c|}{ Parameter } & Nilai \\
\hline Kerapatan fluks & 1 Tesla \\
PermeAbilitas relatif magnet & 1,1 \\
Jumlah koil /kutub f asa & 1 \\
Lebar celah udara & $1 \mathrm{~mm}$ \\
Jumlah alur stator & 54 alur \\
Radius dalam stator & $0,0738 \mathrm{~m}$ \\
Radius luar stator & $0,17 \mathrm{~m}$ \\
Diameter luar stator & $0,340 \mathrm{~m}$ \\
Panjang efektif stator & $0,103 \mathrm{~m}$ \\
Lebar yoke stator & $0,0412 \mathrm{~m}$ \\
Lebar bukaan alur stator & $0,00288 \mathrm{~m}$ \\
Lebar gigi atas stator & $0,00571 \mathrm{~m}$ \\
Lebar gigi stator & $0,0045 \mathrm{~m}$ \\
Lebar alur stator & $0,0112 \mathrm{~m}$ \\
Kedalaman alur stator & $0,0226 \mathrm{~m}$ \\
Luas alur stator & $111,93 \mathrm{~m}$ \\
\hline
\end{tabular}

\section{B. Pengumpulan data} data

Berikut ini adalah urutan dalam pengumpulan

\section{1) Persiapan Alat}

Pada proses pengumpulan data, ada beberapa alat yang perlu disiapkan, antara lain adalah fluke, stroboskop, dan juga vibratiometer. Terlebih dahulu sebelum dilakukan pengambilan data, semua komponen dirakit dengan baik, seperti misalnya pemasangan pulley pada motor penggerak diatur kelurusan dan kekencangannya sehingga tidak terjadi kerugian yang tidak perlu. Selanjutnya semua benda uji dan alat uji akan tersusun seperti yang terlihat pada Gambar 1 dibawah ini.

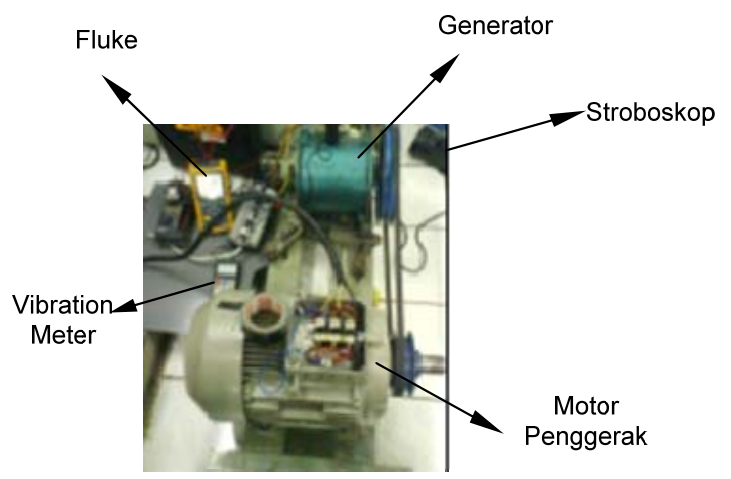

Gambar 1. metode pengukuran respon getaran.

\section{2) Pengukuran variasi kecepatan}

Pertama, motor penggerak diatur kecepatan putarnya sedemikian rupa sehingga putaran yang dihasilkan oleh generator sesuai dengan kecepatan putar yang diinginkan, yaitu kelipatan $100 \mathrm{rpm}$ sampai dengan $600 \mathrm{rpm}$.
3) Pengukuran respon getaran

Dalam hal ini respon getaran akan diukur dengan vibratiometer pada tiga titik sumbu pada permukaan luar generator, seperti yang terlihat pada Gambar 2. Titik yang diambil data adalah arah horizontal, vertikal, dan axial. Pengumpulan data getaran berisikan variasi arah pengukuran pada saat tanpa beban maupun dengan pembebanan. Dimana data keluaran yang akan dicatat adalah kecepatan dan percepatan, data yang diambil adalah rata-rata nilai dari beberapa kali percobaan.
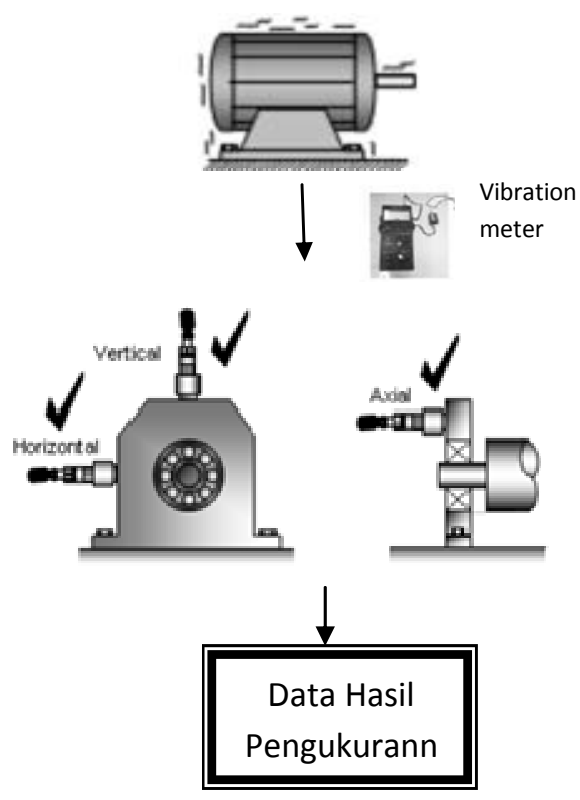

Gambar 2. Diagram pengambilan data.

\section{HASIL PENGUJIAN}

Struktur geometri komponen yang ada pada generator akan sangat mempengaruhi bentuk gelombang dan amplitudo. Desain generator yang diuji terdiri dari komponen utama yaitu poros pemutar dan rotor seperti ditunjukkan pada Gambar 3 dibawah ini.
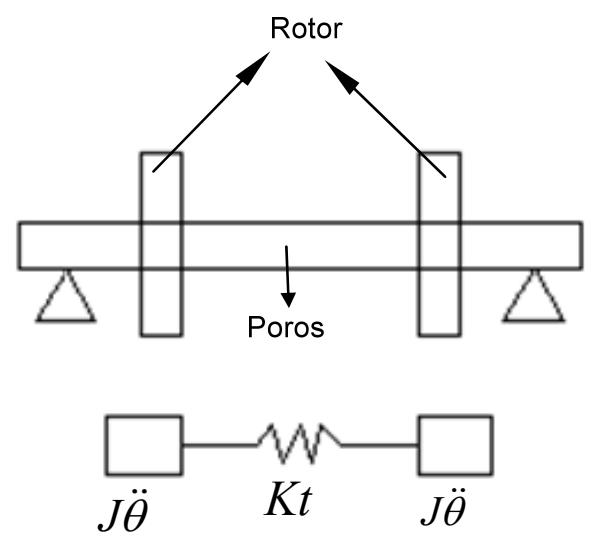

Gambar 3. Skema susunan pada generator

Pada gerak harmonik persamaannya yang standar adalah sebagai berikut : 


$$
\begin{aligned}
& \theta=A \operatorname{Sin} \omega t \\
& \dot{\theta}=A \operatorname{Cos} \omega t \\
& \ddot{\theta}=-\omega^{2} A \operatorname{Sin} \omega t
\end{aligned}
$$

Dimana $\theta$ adalah jarak getaran, $\dot{\theta}$ adalah kecepatan getaran, $\ddot{\theta}$ adalah percepatan getaran, dan A adalah amplitudo getaran. Skema pada Gambar 3 menunjukkan bahwa komponen putar yang bekerja adalah poros dan rotor. Dimana kekakuan pada poros $(\mathrm{Nm} / \mathrm{rad})$ adalah

$$
K t=I p \frac{G}{L}
$$

Momen inersia polar penampang pada poros adalah

$$
I p=\frac{\pi d^{4} G}{32 L}
$$

adapun $\mathrm{d}$ adalah diameter poros, $\mathrm{G}$ adalah modulus elastis geser pada poros, dan L adalah panjang poros uji. Dari persamaan (4) dan (5) didapat persamaan

$$
\mathrm{Kt}=\frac{\pi d^{4} G}{32 L}
$$

Frekuensi pribadi yang terjadi didalam sistem adalah

$$
\omega_{n}=\sqrt{\frac{K t}{\left(J_{1}+J_{2}\right)}}
$$

Adapun $J 1=J 2$ yaitu inersia rotor 1 dan 2 . Dikarenakan dalam sistem terdapat medan magnet yang cukup besar, maka terdapat redaman getaran yang terjadi. Akibat terjadi redaman, pengurangan algoritma $(\delta)$ akibat beda amplitudo yang terjadi saat kecepatan generator $600 \mathrm{rpm}$ adalah

$$
\delta=\ln \frac{Y_{1}}{Y_{2}}
$$

Dimana $\mathrm{Y}_{1}$ adalah puncak Amplitudo 1 dan $\mathrm{Y}_{2}$ adalah puncak amplitudo 2 .

Setelah itu akan didapat nilai rasio redaman $(\xi)$ yang terjadi sebesar

$$
\xi=\frac{\delta}{2 \pi}
$$

Sehingga dari persamaan diatas didapat nilai frekuensi teredam sebesar

$$
\omega_{d}=\omega_{n} \sqrt{1-\xi}
$$

Sehingga apabila dikonversi dalam bentuk Hertz akan didapat

$$
f=\frac{\omega_{d}}{2 \pi}
$$

Sehingga Tabel hasil perhitungan dari persamaan diatas adalah sebagai berikut.

Tabel 4.

Hasil perhitungan

\begin{tabular}{|l|l|}
\hline \multicolumn{1}{|c|}{ Keterangan } & \multicolumn{1}{c|}{ Nilai } \\
\hline Kekakuan poros $(K t)$ & $196782,84(\mathrm{Nm} / \mathrm{rad})$ \\
\hline Frekuensi pribadi $\left(\omega_{n}\right)$ & $4679,49(\mathrm{rad} / \mathrm{det})$ \\
\hline $\begin{array}{l}\text { Pengurangan algoritma } \\
\text { akibat redaman }(\delta)\end{array}$ & 0,46 \\
\hline Rasio redaman $(\xi)$ & 0,74 \\
\hline Frekuensi teredam $\left(\omega_{d}\right)$ & $4503,18(\mathrm{rad} / \mathrm{det})$ \\
\hline Frekuensi teredam $(f)$ & $717,067(\mathrm{~Hz})$ \\
\hline
\end{tabular}

Nilai frekuensi getaran pada sistem adalah $717,067 \mathrm{~Hz}$, sehingga hal ini menunjukkan standar DIN EN 60034-14, dapat dipakai dalam sistem ini.

\section{A. Pengujian Tanpa Beban}

Pengukuran pertama dilakukan kondisi generator tanpa dibebani. Hasil pengukuran getaran pada generator saat tanpa beban dapat dilihat pada Tabel 5 dibawah ini.

Tabel 5.

Hasil pengukuran respon getaran tanpa beban

\begin{tabular}{|c|c|c|c|c|c|c|}
\hline \multirow{2}{*}{$\begin{array}{c}\omega \\
(\mathrm{rpm})\end{array}$} & \multicolumn{2}{|c|}{ Kecepatan $(\mathrm{mm} / \mathrm{s})$} & \multicolumn{3}{|c|}{ Percepatan $\left(\mathrm{mm} / \mathrm{s}^{2}\right)$} \\
\cline { 2 - 7 } & $\mathrm{x}$ & $\mathrm{y}$ & $\mathrm{z}$ & $\mathrm{x}$ & $\mathrm{y}$ & $\mathrm{z}$ \\
\hline 100 & 0,6 & 0,5 & 0,5 & 0,5 & 0,5 & 0,5 \\
\hline 200 & 0,3 & 0,2 & 0,5 & 0,2 & 0,5 & 0,3 \\
\hline 300 & 0,3 & 0,2 & 0,2 & 0,5 & 0,4 & 0,2 \\
\hline 400 & 0,7 & 0,7 & 0,6 & 1,2 & 1,1 & 1,6 \\
\hline 500 & 2 & 1,2 & 2,5 & 1,1 & 0,9 & 1,6 \\
\hline 600 & 2,9 & 2,2 & 3,5 & 0,5 & 0,4 & 0,7 \\
\hline
\end{tabular}

Harga respon pada Tabel 5 diatas merupakan hasil yang didapat dari pengukuran secara langsung. Kecepatan akan terlihat dengan karakteristik kurva sebagai berikut. 


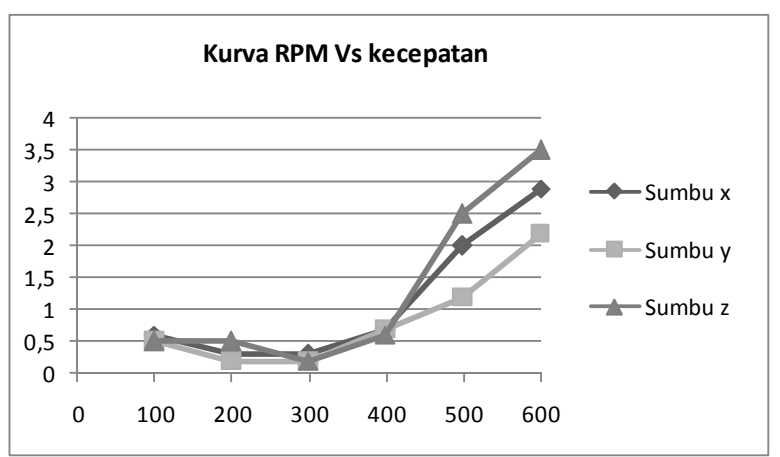

Gambar 4 Kurva RPM Vs Kecepatan

Seperti yang terlihat pada Gambar 4, pada pengamatan respon getaran untuk pengukuran kecepatan diketahui bahwa titik tertinggi terdapat pada pengukuran arah sumbu $\mathrm{z}$, dengan kecepatan putar $600 \mathrm{rpm}$ (axial), yaitu sebesar 3,5 $\mathrm{mm} / \mathrm{s}$. Sedangkan titik paling rendah terdapat pada sumbu y dan sumbu $\mathrm{z}$ yaitu sebesar 0,2 $\mathrm{mm} / \mathrm{s}$.

Harga respon pada Tabel 5 untuk pengukuran percepatan $\left(\mathrm{mm} / \mathrm{s}^{2}\right)$, memiliki karakteristik seperti ditunjukkan oleh kurva pada Gambar 5 dibawah ini.

Tabel 6.

Hasil pengukuran jarak respon getaran tanpa beban

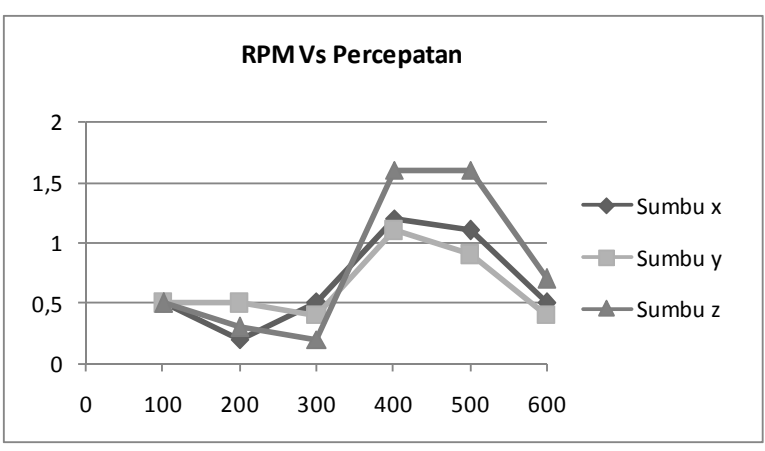

Gambar 5. RPM Vs Percepatan

Seperti yang terlihat pada Gambar 5, pada pengamatan respon getaran untuk pengukuran percepatan diketahui titik tertinggi terjadi pada sumbu z pada kecepatan $400 \mathrm{rpm}$ dan $500 \mathrm{rpm}$ yaitu sebesar $1,6 \mathrm{~mm} / \mathrm{s}^{2}$. Sedangkan titik paling rendah sebesar $0,2 \mathrm{~mm} / \mathrm{s}^{2}$.

Dengan melihat bahwa besar amplitudo adalah

$$
\mathrm{A}=\frac{\theta}{\operatorname{Sin} \omega t}
$$

Maka untuk arah axial, vertikal, maupun horizontal didapat nilai Amplitudo Torsional dan Jarak seperti ditunjukkan pada Tabel 6 .

\begin{tabular}{|c|c|c|c|c|c|c|}
\hline \multirow{2}{*}{$\omega(\mathrm{rpm})$} & \multicolumn{2}{|c|}{ Amplitudo Torsional $(\mathrm{mm})$} & \multicolumn{3}{|c|}{ Jarak $(\mathrm{mm})$} \\
\cline { 2 - 7 } & $\mathrm{Ax}$ & $\mathrm{Ay}$ & $\mathrm{Az}$ & $\theta \mathrm{x}$ & $\theta \mathrm{y}$ & $\theta \mathrm{z}$ \\
\hline 100 & 0,6 & 0,5 & 0,5 & $4,7 \times 10^{-2}$ & $4,8 \times 10^{-2}$ & $4,7 \times 10^{-2}$ \\
\hline 200 & 0,3 & 0,2 & 0,5 & $9,5 \times 10^{-3}$ & $2,4 \times 10^{-2}$ & $1,4 \times 10^{-2}$ \\
\hline 300 & 0,3 & 0,2 & 0,2 & $1,5 \times 10^{-2}$ & $1,3 \times 10^{-2}$ & $6,3 \times 10^{-3}$ \\
\hline 400 & 0,7 & 0,7 & 0,6 & $2,8 \times 10^{-2}$ & $2,6 \times 10^{-2}$ & $3,8 \times 10^{-2}$ \\
\hline 500 & 2 & 1,2 & 2,5 & $2,1 \times 10^{-2}$ & $1,7 \times 10^{-2}$ & $3,0 \times 10^{-2}$ \\
\hline 600 & 2,9 & 2,2 & 3,5 & $7,9 \times 10^{-3}$ & $6,3 \times 10^{-3}$ & $1,1 \times 10^{-3}$ \\
\hline
\end{tabular}

Dari hasil pengukuran di dapat nilai tertinggi jarak respon getaran tanpa beban sebesar $4,8 \mathrm{x}$ $10^{-2} \mathrm{~mm}$ yaitu pada arah sumbu y. Gambar 6 dibawah ini adalah karakteristik kurva hasil pengukuran jarak respon getaran tanpa beban.

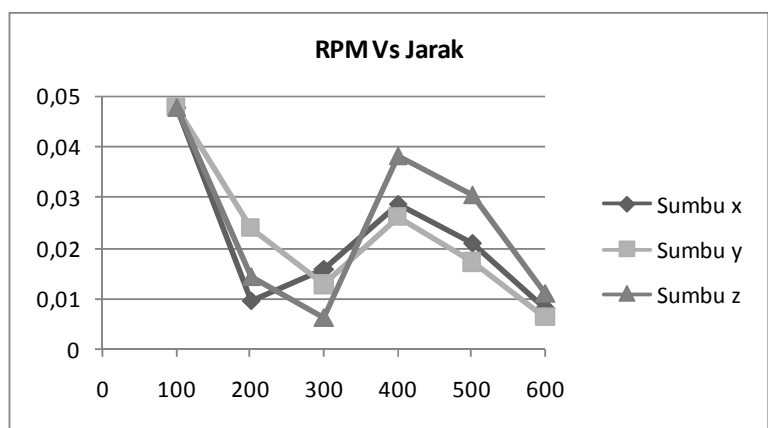

Gambar 6. RPM Vs Jarak
Seperti yang terlihat pada Gambar 6, pada pengamatan respon jarak getaran nilai yang diperoleh bervariasi, hanya saja setelah melewati kecepatan $400 \mathrm{rpm}$ terdapat kecenderungan bahwa nilai jarak getaran $(\mathrm{mm})$ menurun.

\section{B. Pengujian dengan Beban $300 \mathrm{~W}$}

Pengukuran kedua dilakukan pada kondisi dimana generator diberi beban sebesar $300 \mathrm{~W}$. Pembebanan dilakukan berdasarkan kapasitas maksimum pembebanan yang mampu dilakukan di Laboratorium Elektronika Daya Pusat Penelitian Tenaga Listrik dan Mekatronik - LIPI yaitu $300 \mathrm{~W}$. Hasil pengukuran getaran pada generator saat diberi beban sebesar $300 \mathrm{~W}$ dapat dilihat pada Tabel 7 dibawah ini. 
Tabel 7.

Hasil pengukuran respon getaran dengan beban $300 \mathrm{~W}$.

\begin{tabular}{|c|c|c|c|c|c|c|}
\hline \multirow{2}{*}{$\begin{array}{c}\omega \\
(\mathrm{rpm})\end{array}$} & \multicolumn{2}{|c|}{ Kecepatan $(\mathrm{mm} / \mathrm{s})$} & \multicolumn{3}{c|}{ Percepatan $\left(\mathrm{mm} / \mathrm{s}^{2}\right)$} \\
\cline { 2 - 7 } & $\mathrm{x}$ & $\mathrm{y}$ & $\mathrm{z}$ & $\mathrm{x}$ & $\mathrm{y}$ & $\mathrm{z}$ \\
\hline 100 & 0,4 & 0,4 & 0,6 & 0,6 & 0,6 & 0,7 \\
\hline 200 & 0,3 & 0,8 & 0,4 & 1,4 & 1,3 & 1,1 \\
\hline 300 & 0,8 & 0,5 & 0,6 & 0,1 & 0,3 & 0,4 \\
\hline 400 & 0,9 & 0,9 & 0,4 & 2,8 & 2,1 & 1,3 \\
\hline 500 & 0,8 & 0,3 & 0,5 & 1,1 & 0,9 & 0,4 \\
\hline 600 & 0,9 & 0,4 & 0,5 & 1,3 & 0,9 & 0,4 \\
\hline
\end{tabular}

Harga respon pada Tabel 7 diatas merupakan hasil yang didapat dari pengukuran secara langsung kecepatan, dengan karakteristik sebagai berikut.

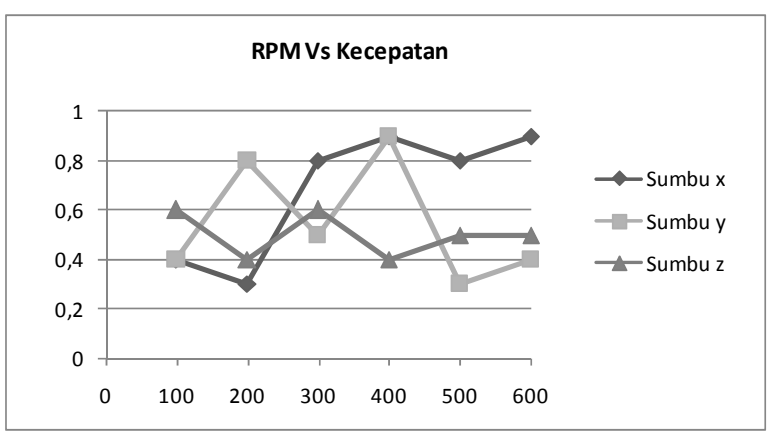

Gambar 7. RPM Vs Kecepatan

Pada pengamatan pada Gambar 7 ukuran kecepatan akan diketahui titik paling tinggi terdapat pada pengukuran arah sumbu x pada putaran $400 \mathrm{rpm}$ dan $600 \mathrm{rpm}$ yaitu sebesar 0,9 $\mathrm{mm} / \mathrm{s}$. Sedangkan titik paling rendah terjadi pada sumbu x pada kecepatan putar $200 \mathrm{rpm}$ yaitu sebesar $0,3 \mathrm{~mm} / \mathrm{s}$.
Sedangkan harga respon pada Tabel 7 untuk pengukuran percepatan, mempunyai karakteristik seperti ditunjukkan pada kurva pada Gambar 8 dibawah ini.

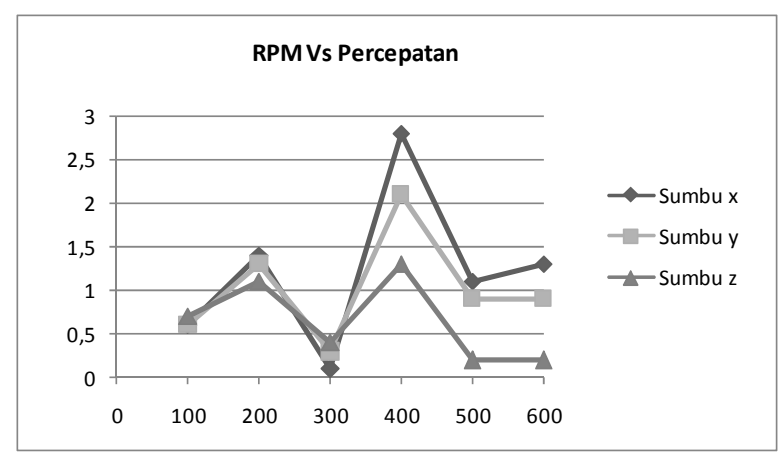

Gambar 8. RPM Vs Percepatan

Seperti yang terlihat pada Gambar 8, pada pengamatan respon getaran untuk pengukuran percepatan diketahui mempunyai titik paling tinggi terjadi pada sumbu x pada putaran $400 \mathrm{rpm}$ yaitu sebesar $2,8 \mathrm{~mm} / \mathrm{s}^{2}$. Sedangkan titik paling rendah terjadi pada sumbu $\mathrm{x}$ pada kecepatan putar $300 \mathrm{rpm}$ yaitu sebesar $0,1 \mathrm{~mm} / \mathrm{s}^{2}$.

Bila amplitudo untuk jarak, kecepatan dan percepatan dianggap sama, maka

$$
\frac{\theta}{\operatorname{Sin} \omega t}=\frac{\dot{\theta}}{\omega \operatorname{Cos} \omega t}=\frac{\ddot{\theta}}{\omega^{2} \operatorname{Sin} \omega t}
$$

Sehingga

$$
\frac{\ddot{\theta}}{\dot{\theta}}=\frac{\omega \operatorname{Sin} \omega t}{\operatorname{Cos} \omega t}
$$

Maka untuk arah axial, vertikal, maupun horizontal didapat nilai Amplitudo Torsional dan Jarak seperti Tabel 8 dibawah ini.

Tabel 8.

Hasil perhitungan jarak respon getaran dengan beban $300 \mathrm{~W}$

\begin{tabular}{|c|c|c|c|c|c|c|}
\hline \multirow{2}{*}{$\begin{array}{c}\omega \\
(\mathrm{rpm})\end{array}$} & \multicolumn{2}{|c|}{ Amplitudo Torsional $(\mathrm{mm})$} & \multicolumn{3}{|c|}{ Jarak $(\mathrm{mm})$} \\
\cline { 2 - 7 } & $\mathrm{Ax}$ & $\mathrm{Ay}$ & $\mathrm{Az}$ & $\theta \mathrm{x}$ & $\theta \mathrm{y}$ & $\theta \mathrm{z}$ \\
\hline 100 & 0,4 & 0,4 & 0,6 & $5,7 \times 10^{-2}$ & $5,8 \times 10^{-2}$ & $6,69 \times 10^{-2}$ \\
\hline 200 & 0,3 & 0,8 & 0,4 & $6,66 \times 10^{-2}$ & $6,2 \times 10^{-2}$ & $5,2 \times 10^{-2}$ \\
\hline 300 & 0,8 & 0,5 & 0,6 & $3,2 \times 10^{-3}$ & $9,5 \times 10^{-3}$ & $1,3 \times 10^{-2}$ \\
\hline 400 & 0,9 & 0,9 & 0,4 & $6,66 \times 10^{-2}$ & $5 \times 10^{-2}$ & $3,1 \times 10^{-2}$ \\
\hline 500 & 0,8 & 0,3 & 0,5 & $2,1 \times 10^{-2}$ & $1,7 \times 10^{-2}$ & $3,8 \times 10^{-3}$ \\
\hline 600 & 0,9 & 0,4 & 0,4 & $2,1 \times 10^{-2}$ & $1,4 \times 10^{-2}$ & $3,2 \times 10^{-3}$ \\
\hline
\end{tabular}

Seperti yang ditunjukkan pada Tabel 8, hasil pengukuran menunjukkan bahwa nilai tertinggi dan nilai terendah jarak respon getaran dengan beban $300 \mathrm{~W}$ terdapat pada sumbu z. Nilai tertinggi sebesar $6,69 \times 10^{-2} \mathrm{~mm}$ yang terletak pada arah sumbu z, dengan kecepatan putar 100 rpm. Sedangkan titik paling rendah juga terdapat pada sumbu $\mathrm{z}$ pada kecepatan $600 \mathrm{rpm}$ yaitu sebesar $3,2 \times 10^{-3} \mathrm{~mm}$. 
Harga respon getaran dengan beban $300 \mathrm{~W}$ yang ditunjukkan pada Tabel 8 memiliki karakteristik seperti ditunjukkan oleh kurva pada Gambar 9 dibawah ini.

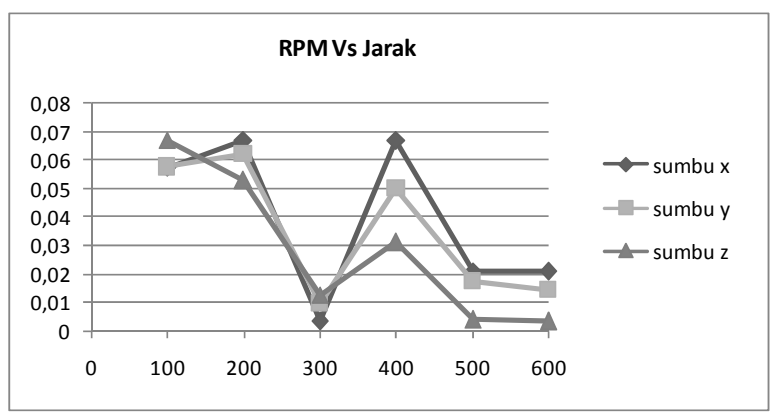

Gambar 9. RPM Vs Jarak

Seperti yang terlihat pada gambar 9, hasil pengamatan menunjukkan bahwa jarak respon getaran mempunyai nilai yang bervariasi. Hanya saja setelah kecepatan putar generator mencapai $400 \mathrm{rpm}$ terjadi kecenderungan nilai jarak respon getaran menurun.

\section{KESIMPULAN}

\section{A. Kesimpulan}

Adapun kesimpulan dari hasil pengamatan dan perhitungan pada penelitian ini ditunjukkan pada poin-poin berikut :

1. Hasil pengukuran respon kecepatan getaran secara langsung untuk generator tanpa beban nilai tertinggi pada arah sumbu $\mathrm{z}$ yaitu sebesar $3,5 \mathrm{~mm} / \mathrm{s}$, sedangkan untuk pengukuran percepatan tertinggi pada arah sumbu z yaitu sebesar $1,6 \mathrm{~mm} / \mathrm{s}^{2}$.

2. Hasil pengukuran kecepatan respon getaran secara langsung untuk generator dengan beban $300 \mathrm{~W}$, nilai tertinggi pada arah sumbu $\mathrm{x}$ yaitu sebesar $0,9 \mathrm{~mm} / \mathrm{s}$, sedangkan untuk pengukuran percepatan tertinggi pada arah sumbu $x$ yaitu sebesar $2,8 \mathrm{~mm} / \mathrm{s}^{2}$.

3. Hasil perhitungan jarak untuk generator tanpa beban nilai tertinggi dengan nilai $4,8 \mathrm{x}$ $10^{-2} \mathrm{~mm}$ pada arah sumbu $\mathrm{y}$, sedangkan pengukuran untuk generator dengan pembebanan $300 \mathrm{~W}$ adalah dengan nilai 6,69 x $10^{-2} \mathrm{~mm}$ pada arah sumbu $\mathrm{z}$.

4. Berdasarkan Tabel IEC 34-14 dan DIN EN 60034-14 pada putaran $600 \mathrm{rpm}$, kecepatan getaran yang diijinkan adalah $1,8 \mathrm{~mm} / \mathrm{s}$, sehingga hasil pengujian getaran pada generator tanpa beban, nilai kecepatan paling besar adalah $3,5 \mathrm{~mm} / \mathrm{s}$, menunjukkan bahwa dalam kondisi tanpa pembebanan generator tersebut belum memenuhi kualifikasi yang tertera pada standar IEC 34-14.
5. Pada hasil pengujian respon kecepatan getaran pada generator dengan pembebanan $300 \mathrm{~W}$, hasilnya relatif lebih kecil dan stabil dari pengujian generator tanpa pembebanan yaitu $0,9 \mathrm{~mm} / \mathrm{s}$.

\section{B. Saran}

Penulis menyarankan untuk melakukan riset lanjutan yang lebih terfokus untuk meneliti tentang variabel yang menyebabkan besarnya nilai kecepatan getaran pada generator tanpa pembebanan melebihi standart yang ditentukan, misalnya kelonggaran komponen ataupun keausan komponen generator.

\section{DAFTAR Pustaka}

[1] Prakash, S., Puri, V, 2006, "Foundation for Vibrating Machines", the Journal of Structural Engineering, SERC, Madras, India April-May.

[2] Smeisme, A., Saklawi, R., and Yassine, w., 2008, "A Predictive Maintenance Tool: Vibration Analysis to Determine the Condition of Electric Machines", ARISER Vol. 4 No. 3 (2008) 103-117, Electrical and Computer Department, American University of Beirut, LEBANON, 23 June 2008.

[3] Jayaswal, P, Wadhwani, A., and. Mulchandani, B., 2008, "Machine Fault Signature Analysis", Hindawi Publishing Corporation International Journal of Rotating Machinery Volume 2008, 21 January.

[4] Oliquino, R., Islam, S., and Eren, H., 2002, "Effects of Types of Faults on Generator Vibration Signatures", School of Electrical and Computer Engineering Curtin University of Technology, Western Australia. [Online]. Available: www.itee.uq.edu.au/ aupec/aupec03/.../00 8\%20Oliquino\%20paper.pdf.

[5] Setimi, A., 2010, " Electric Motor Vibration", Australia. [Online]. Available: http://www.weg.com.br.

[6] Energy-efficient motors according to IEC/DIN High efficiency motors according to EPAct. - for low voltage with squirrelcage rotor, 1999, [Online]. Available: www.mahykhoory.com/pdf/W21R_E.PDF.

[7] Irasari, Pudji dan Hidayati, D, Nurafni, , 2006, "Analisis Prototipe Generator Kecepatan Rendah Untuk Pembangkit Listrik Skala Kecil", Majalah Teknologi Indonesia Volume 29, Nomor 1 2006: pp 47-51. 
[8] C.B. Williams, A. Pavic, R.S. Crouch, R.C. Woods. "Feasibility study of vibration-electric generator for bridge vibration sensors", IMAC-XVI Proceedings, Sheffield, United Kingdom, 1997.

[9] Hariyotejo, P., Helian, J., Pramono, G., Ridwan, A., 2008, "Pengembangan Generator Mini Dengan Menggunakan Magnet Permanen", Departemen Teknik Mesin, Program Pasca Sarjana, Fakultas Teknik Universitas Indonesia, Jakarta, Indonesia. [Online]. Available: images.sudarjanto.multiply.com /.../pengembangan-generator-mini-denganmenggunakan-magnet-permane1.pdf. 